\title{
Information Behavior of Fracture Therapist in Citapen Village, West Bandung Regency, Indonesia
}

\author{
${ }^{1}$ RULLY KHAIRUL ANWAR, ${ }^{2}$ UTE LIES SITI KHADIJAH, ${ }^{3}$ DIAH FATMA SJORAIDA \\ 1,2,3 Universitas Padjadjaran, Jl. Raya Bandung-Sumedang KM. 21 Jatinangor, Indonesia \\ email: ${ }^{1}$ rully.khairul@unpad.ac.id; ${ }^{2}$ ute.lies@unpad.ac.id; ${ }^{3}$ diah.fatma@unpad.ac.id.
}

\begin{abstract}
Citapen village is a fracture clinic village that applies traditional medicine rich of local knowledge. The fracture therapist has a different paradigm with local health institution. Therefore, this research aims to discover the information behaviour of (bone) fracture therapist. This research uses a qualitative approach with a case study method through interview, observation, and literature review. The research results show the needs of traditional medicine information are related to economic, social and cultural needs. The information seekers are searching for traditional medicine information from both internal and external sides. In information evaluation, the therapist searches information on the traditional medicine in Citapen Village, which is then applied to the patients, from one to another. The existence of traditional medicine which is rich in local knowledge in Citapen village has not been appropriately documented. However, the information is still able to be well memorized by being inherited from generations. Even though there are many clinics built in the village, when it comes to bone fracture, many people will go to fracture therapist to get traditional medicine.
\end{abstract}

Keywords: information behaviour, citapen village, fracture therapist

\section{Introduction}

Traditional medicine is the resulting work of the community in using the natural resources exist in their nearby surroundings. The oldest persons who live in one particular area will know more about the plants' wealth to be used as traditional medicine, and then they spread that knowledge to their family members or people in their surroundings. Zulkifli (2004) states that traditional medicine had long lived in the community and can be used for various kind of health problem. The community learn independently of how to treat illness by judging the symptoms. Moreover, the source of traditional medicine from plants have spread in the community so that they can reduce the cost from both chemical and economic sides.

Traditional medicine using traditional plants provides many benefits for the community, both in terms of environment and economy. From environmental side, the community preserves traditional plants, while from economic side, traditional medicine adds economic value to the family's livelihood. Wati (2019) states that the government has strived to maintain traditional plants as traditional medicine through a "back to nature" program, namely the utilization and preservation of traditional plants program in the community. One of the villages that still use traditional medicine is Citapen Village, which is specially mixed by fracture therapists themselves. Citapen Village is the village with many fracture clinics. Viewing from cultural aspect, some therapists use traditional medicine to continue their ancestor heritage to treat fracture patients. While from social aspect, the fracture therapists directly interact with the patient while giving traditional medicine. Fracture therapists do not use the medical instrument that can't be bought by the patients; they use medical fracture therapy tools made of wood to make the patient feels comfortable during the treatment.

The community find it easier to get 
treatment from fracture therapists because sometimes there are patients who need to get regular treatment. This reduces costs economically for patients, especially for those who live in rural areas. The community feels that the costs and treatment procedures at public hospitals are quite burdensome so that the existence of fracture clinics in Citapen Village has helped reduce their health costs. In addition, some therapists can help broken bones patients based on their good intentions, which in turn develop a sense of brotherhood between the therapist and the patient.

Lioutas (2014) states that the community search and use health information from an internal and external source of their surroundings, including in consuming traditional medicine. It begins with their need to consume traditional medicine, and then they find health information about it and use it to solve their health problems (Pang et al., 2015).

In Citapen Village, patients with fractures need information of traditional medicine to reduce their pain. The therapists search for information about traditional medicine usage from local knowledge surroundings. "Information as the source of present and future communication flow is very instrumental in accident prevention" (Fakhri et al., 2018).

Therefore, local knowledge of traditional medicine as the ancestor heritage of Citapen village become health information source in fulfilling the community health information. Knowledge of traditional medicine has been maintained by transferring that knowledge from old therapist to the young ones and then applied it to the fracture patients. This is a unique phenomenon that traditional medicine is still used by the people in the village, particularly, by those who suffer from bone fractures. That is why this article focuses more on describing the behaviour of searching for information about traditional medicine as the local knowledge of Citapen Village community.

People/human can get knowledge based on experience (tacit) and written knowledge (explicit). Knowledge based on the experience will influence someone's behaviour from generation to the next in a certain community, that is called local knowledge (Anwar, 2012). People who live in the same area of environment or have the same purpose will form local knowledge which will be passed down from generation to generation in the community with local knowledge, Wilson
(1996) on Kundu, (2017), state that they process and use information as an essential part of the feedback on getting information. The community in Citapen Village is in the category of social information since they search for information by themselves (being independent) and use it for their own (and others') good.

Knowledge inherited from the ancestor depends on the creation of the knowledge itself. Local knowledge based on experience is created from word of mouth which then emerge sharing concept and concept about family medicine plants (Saepudin, E., Rusmana, A., \& Budiono, 2016). Traditional medicine can also be called family's medicinal plants, namely traditional medicine that has been living with and used as daily medicine in the families of rural area. The community becomes independent in managing their health by the help of those herbal plants. It becomes their special local wisdom. If they live in a different geographical condition, they also have different plants and have a different method of how to manage those medicinal herbs.

Local knowledge of traditional medicine is continuously inherited. It is carried out to avoid the extinction of old knowledge about traditional treatment from the old generation to the new generation. Anwar, $R$. K., Rizal, E., \& Saepudin (2015) describe the important literation of backyard medicinal plants for students at school. Students, as part of a new generation, need to know about medicinal herbs which can be found in their surroundings. By doing so, they will have the awareness to take care of their environment and use natural wealth.

It is the same thing with the case of patients with bone fractures that are helped to be recovered by the treatment of traditional medicine. People in rural area who suffer fron bone fractures will go to fracture therapists to get clinic treatment. Most of the fracture therapists use traditional medicine as outside the body treatment. Kurnia, S. H., Kosasih, C. E., Prawesti P., (2012), who took their respondents to the fracture clinic in Sumedang district, stated that the patients who went there have a high motivation to recover. Some of them said they also got recovered from health institution but have problems with the high cost of the treatment.

Moreover, Suryana, F., Iskandar (2014) give a new knowledge that medicinal herbs planted in the house yard in Cibunar Village, 
Rancakalong subdistrict in Sumedang District, start to develop into entrepreneurship. Rural community begins to use medicinal herbs not only for taking care and treating their family's health but also to sell them to public. They mix medicinal herbs into traditional medicine which is needed by the community outside their village. Medicinal herbs as a traditional medicine have values for health and also increase the economy of rural community.

Williamson (2005) even maps traditional medicine through traditional treatment. According to him, several traditional medicines that have already been tested in industry clinics such as St John's Wort, Ginkgo biloba, Dan shen, Liquorice, Ma Huang, and garlic can interact with traditional medicine to cure some diseases. Traditional medicine that has already been tested and being branded by industry institutions evidently in use can be combined with traditional medicine of self mixture, as long as there is a safety process for the patient. In healing the fractures, combination of both traditional medicines and chemical drugs can be done as long as the therapist gives his full attention to the patient who consumes it. It is also crucial to have a suggestion or recommendation from doctors/ health expert of health institution.

Information about how to use traditional medicine is needed by the therapist and fracture patients. Fracture therapist needs the information of traditional medicine to set a standard of medication administration to the patient, whereas the patient needs the information of traditional medicine to cure his fraction safely. Lioutas (2014) states that, "Human information behaviour is a complex and multidimensional system which function when the person recognizes a need-that can be met through information intakeand includes all the activating mechanisms that lead to the information seeking, the actual process of information seeking, and that of information processing and use". The information has a complete unity starts from the need of information, search for the information, and use the information.

Wilson (1981) and Belkin, Oddy, and Brooks (1982) in Lioutas (2014) wrote that information needs not only for ourselves but naturally become the goal of those needs. Therefore, all the information from any other life fields is also needed. For example, information in the health field. All this time, Citapen Village as the healing of fracture village, has a local method in using traditional medicine by the fracture therapist to the patient. Old traditional medicine knowledge in Citapen Village has already existed since a long time ago before the presence of fracture clinics. This knowledge remains to exist through passing down process from the former fracture therapist to the next therapist continuously.

This article tries to focus the analysis on the information behaviour of fracture therapist in using traditional medicine and to find out local knowledge of traditional medicine of the fracture therapists in Citapen village. Lioutas (2014) has given the concept related to information behaviour, searching the information, and information usage. Wilson (2005) in Bawden, (2006) explains that the information needs will determine the information to be search for. Besides that, fracture therapists, in giving the traditional medicine, must fulfill the standard of traditional treatment in accordance with the regulation of the Health Minister of the Republic of Indonesia.

After being able to manage the information needs about traditional treatment, fracture therapist then searches the information through information sources reachable and near them, namely family, friend, literature, and online source. Lioutas (2014) states that searching the information is the way to fulfill the information needs, develop the information, and a strategy to find the information. Generally, fracture therapists have already known every background of their fracture patients. Thus, they have data on what patient traditional medicine need and search for more additional information from the trusted source.

After finding the information they need, then the fracture therapists begin to evaluate. They do choose the traditional medicine information that the patient needs. Lioutas (2014) states there are two steps. First, the user does evaluate the information without having the skill in analyzing. Second, the user uses a trusted evaluation source for assessing the data. The existence of various information on the usage make the former statement of information was not valid or legitimate. Then, the user continuously tries to use the correct information so that at last, he/she knows what information he/she will use.

Based on the focus of analysis, we can understand the information behavior of in-depth local knowledge. Zhang (2014) in Dubbeldam, I., Sanders, J., Spooren, W., 
Meijman, F. J., \& van den Haak, (2018) reveal that "Information behavior influenced some factors, consisting of demographic, cognitive, affective, situational, and social." The community of Citapen Village has valuable information on traditional medicine that can help people in the lower-class economy to get treatment at a low cost. Based on demographic factor, the community at Citapen Village uses the information of appropriate age and education. For cognitive factor, they have the skill to, "Find, understand, and evaluate information" (Dubbeldam, I., Sanders, J., Spooren, W., Meijman, F. J., \& van den Haak, 2018). For affective factor, they have motivations to use traditional plant for medicine. For situational factor, it is the perception of the community of Citapen Village in the treatment process (Zhang, 2013). For social factor, they understand "Information channels and social rules as an information seeker" (Dubbeldam, I., Sanders, J., Spooren, W., Meijman, F. J., \& van den Haak, 2018); (Sudayasa et al., 2019). Therefore, the researchers hope that the community in Citapen Village will maintain and preserve their local knowledge of traditional treatment. If the community is able to manage the local knowledge, they will have income for their family and their existence as holder of local knowledge.

\section{Research Methodology}

This research uses qualitative approach. Mason (2002) states that the characteristic of qualitative approach is," [...] Systematically, argument [...]." The research question that has been set must be in sequence or systematically then explained and described what has been found in the field related to the theory suitable with the writer's opinions. This research of traditional medicine knowledge tries to describe the results of analysis of findings in Citapen Village from the theory of information behaviour about traditional medicine by fracture therapists.

Patton, M. Q., Cochran (2002) add that question research becomes an important part of the research. In this research, the research question focusses on the information behaviour of traditional medicine of the fracture therapists in Citapen Village. Information behaviour is seen through the fracture therapists who need information about traditional medicine, searching for the information, evaluating and using that information.
The researcher observes the process thoroughly from the information behaviour of traditional medicine which is done by fracture therapist. In order to make the research question more directed, then the suitable research method for this phenomenon in the field is a case study method.

Simons (2009) in Starman (2013) explains that the research method of case study explores more deeply varied complexity perspectives and objects, the policy, institution, and the unique environment program. Flyvbjerg (2011) in Starman (2013) also adds that a case study helps to choose what the researcher wants to research. Then, in this case (subject), research field (object), and choosing case influence one another.

Starman (2013) states that the subject has to connect with the phenomenon of the research and then phenomenon becomes the comparison in analyzing the frame of the research through the object. In this research, we observed the subject research of fraction therapist in Citapen Village. The phenomenon is local knowledge of traditional medicine that is still carried out by fracture therapist. This phenomenon then learns thoroughly into information behaviour done by the fracture therapist.

Yin (2003) in Baxter and Jack, (2008) even give detail explanation that the case study would connect with the research phenomenon if the research focuses able to answer how and why from the research question. Yin (2003) and Stake (1995) in Baxter and Jack, (2008) state that to make the case clear, the researcher can see from the time and place, time and activity, definition and context. Local knowledge of traditional medicine is seen from the past; that is when the ancestors of Citapen Village opened the first clinic of fraction therapist until now continue by their family. Local knowledge of traditional medicine which is done now evidently influence the information behaviour of the therapist traditional medicine. Local knowledge about traditional medicine has two different definitions of natural herbal medicine or herbal treatment results from the tested, industrial clinics.

Base on the phenomenon occurred and research question offered, the case study taken in this research is a descriptive category. Yin (2003) and Stake (1995) in Baxter and Jack, (2008) explain that descriptive study is able to describe the intervention or phenomenon and real-life 
suitable with the context that is happening. The type of case study applied is a single case. This type is a case that searching for answers from many sources; in this research, they are fracture therapist and patients.

In this research, data were collected by using snowball sampling or chain sampling method (Patton, M. Q., Cochran, 2002). This collecting data technique's goal is to identify a solution for the case which is hard to find. The method of collecting data includes interviewing, observing, and reviewing literature. Regarding data interpretation, the research use data triangulation and member checking on the fracture therapist and patient in Citapen Village. The research obtained data from the interview and processed them into transcript interview. The researcher mapped data from this transcript and matched the observation data. Finally, the researcher wrote the data based on the theory and methodology of research.

\section{Results and Discusssion}

\section{The Fracture Therapy}

A rural community in West Bandung district is a community that comes from many areas. There is a combination between the original community and the newcomer community. The community develop together along with the rapid industrial sector and trade. However, that does not influence the community to keep using traditional treatment, especially to heal the bone fracture.

Members of the community who suffer from bone fractures will choose fracture therapy to heal the illness, for example, fracture therapist in and around Citapen area, Cihampelas subdistrict, West Java. It is in the legislation rules called traditional treatment that is conducted especially by fracture therapist. Traditional treatment is identical with traditional medicine made by them. According to the decree of Health Minister of Republic of Indonesia number 1076/ MENKES/SK/VII/2003 on the implementation of traditional medicine in section 1 written that traditional medicine is "materials or mixture of materials from plants, animals, minerals, galenic or material mixture which from generation to generation is used for treatment based on the experience" (Menteri Kesehatan Republik Indonesia, 2003).

Traditional medicine involves organic materials or the making process derives from old knowledge or the heritage of ancestors which is passing down from generation to generation. In line with section 12 of the decree, traditional treatment is conducted as the effort to increase health, to prevent and heal diseases, and to recover the illness (Menteri Kesehatan Republik Indonesia, 2003). In fracture treatment, traditional medicine functions to relieve pain from a bone dislocation, relieve swollen because of the broken bone, and help to connect the broken bone again. Traditional treatment that comes from local knowledge is explained in the decree of Health Minister of Republic of Indonesia number 381/MENKES/SK/III/2007 about the policy of national traditional medicine. It has a part stating that Sundanese community is rich of local wealth where many villages area in West Java have various kinds of medicinal herbs used by the community as herbal medicine (Menteri Kesehatan Republik Indonesia, 2007). Fracture treatment in Citapen village also uses traditional medicine as a rubbing medicine for hands or broken legs.

Traditional treatment is purely using traditional medicines mixed by the therapists themselves. Ismedsyah, Sembiring, (2019) says that in the traditional treatment can be used manual, energy, think process technique with a compound from plants, animals, minerals, and galenika (pharmaceutical plants). Mak Idah and Saefulloh clinics never use chemical medicine for curing their fracture patients because the patients still go to the clinic. When the researcher visited Mak Idah clinic, there was a patient who had a broken leg because of doing excessive exercise. Mak Idah treated the patient diligently and fixed the patient's broken leg by using pounded tubers and then rubbed to the injury part. That also happened in Saefulloh clinic for the patient who had stayed in his house for months. The patient's leg bone was cracked because of a motorcycle accident so that he was not able to walk. In this clinic, he was cured only by the mixture of traditional medicine made by the therapist himself, until at last, the patient recovered as usual, although it needed long weeks.

It is different from Haji Obay clinic. His treatment can be said as a traditional integration treatment combining purely traditional treatment with complementary treatment. This clinic uses traditional medicine mixed by the therapist himself and apply the mixture to the broken part of the body 
and then give antibiotic as a pain reliever. The decree of Health Minister of Republic of Indonesia number 1076/MENKES/SK/ VII/2003 on the implementation of traditional medicine section 18 say that traditional therapist could give traditional medicine which produced by traditional medicine industry that already registered and has a registration number and traditional medicine mixture (Menteri Kesehatan Republik Indonesia, 2003).

Traditional medicine made by faction therapists is a legacy from the wealth of the ancestors of Citapen village and the traditional medicine has been authorized by the Minister of Health of the Republic of Indonesia. To make a clear explanation, the researchers describe it in the Table 1.

Table 1

Result finding at the field

\begin{tabular}{lll}
\hline No. & $\begin{array}{c}\text { The behaviour } \\
\text { of traditional } \\
\text { medicine } \\
\text { information }\end{array}$ & \multicolumn{1}{c}{ Information } \\
\hline 1 & $\begin{array}{l}\text { The information } \\
\text { needed for } \\
\text { traditional } \\
\text { medicine }\end{array}$ & $\begin{array}{l}\text { Economic side, } \\
\text { social, cultural }\end{array}$ \\
\hline $\begin{array}{l}\text { Information search } \\
\text { for traditional } \\
\text { medicine }\end{array}$ & $\begin{array}{l}\text { It is carried out } \\
\text { by finding the } \\
\text { information from } \\
\text { both the internal } \\
\text { and external sides }\end{array}$ \\
\end{tabular}

Source: Research result, 2018

\section{Information Behavior in the Fracture Therapy}

Traditional treatment is local knowledge inheritance that can help the community in the aspects of health, economic, and welfare related to the fracture. From the economic aspect, the community belongs to the middle to the lower economy which will be hard to have treatment with high cost in the hospital. The community is helped by the traditional treatment of fracture clinics in Citapen village. There are even several legislation rules supporting traditional treatment that help the therapist in giving their health service to the community. However, therapists in Citapen village have not directly co-operated with health workers or health institution in West Bandung. For example, interview data showed that the therapist and his patients of fracture practice in Citapen village was popular since along time ago and has helped many people.
Culturally, local knowledge of traditional medicine in Citapen village has already been conducted since the fracture clinic appeared in Citapen village. Some of the people in this village choose to become fracture therapists as their profession as the village ancestor inheritance. There is a therapist who get the knowledge and skill from his former therapist or by mean working as a therapist through the process of learning which take quite a long time. Therapist in Haji Obay clinic (figure 1) said that the existence of clinic treatment adds more relatives (Acep, interview, July 11th, 2018). The attitude and attention of the fracture therapists and the way they cure make the patient feels like they have a new family.

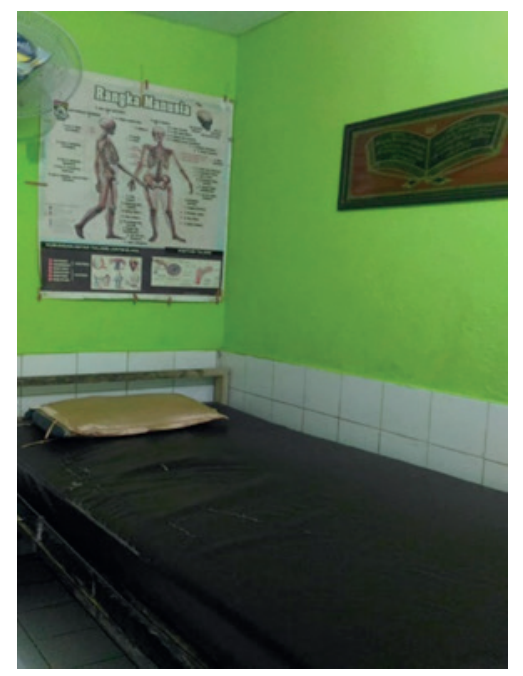

Figure 1. The Haji Obay Clinic

Besides, the young fracture therapists generation have their responsibility to continue the treatment mission, that is to give an easy fracture treatment that makes the community comfortable. Patients with bone fracture need the treatment to heal their bone condition and recover as it was before. The therapist heals them with easy traditional method without using modern medical types of equipment, for example, being treat by traditional medicine. The essence of traditional medicine is sourced from plants in nature. When a human's bone broke, it needs medicine to relieve the swollen and pain, both from outside and inside. The medicine which was taken from nature required the patients to keep patient during the treatment.

Fracture patients being treated in Citapen Village come from many other areas. For example, patients who had an accident and directly went to the fracture clinic said 
that the process of fracture recovery takes time if it is done in the hospital, so they choose to go to the fracture clinic. Most of the patients take the treatment based on their parent's suggestion who have used the treatment in Citapen Village before (Syifa, interview, July 11th, 2018)

Fracture therapists in searching the information of traditional medicine take sources from both internal and external sides. From the internal side, they the information from older persons who built the clinic or from their related family. Information of word mouth become tradition or ritual in Citapen village. Fracture therapists learned to become a therapist for years. For example, therapist Acep in Haji Obay clinic, Asep Saefudin Clinic, and Mak Ida Clinic(figure 2) who had learned since he was little. When he was little, he often saw his parents or his family doing fracture treatment. So when he had come to the appropriate age to become a therapist, he would have to pass through some tests and ritual first before he became one.

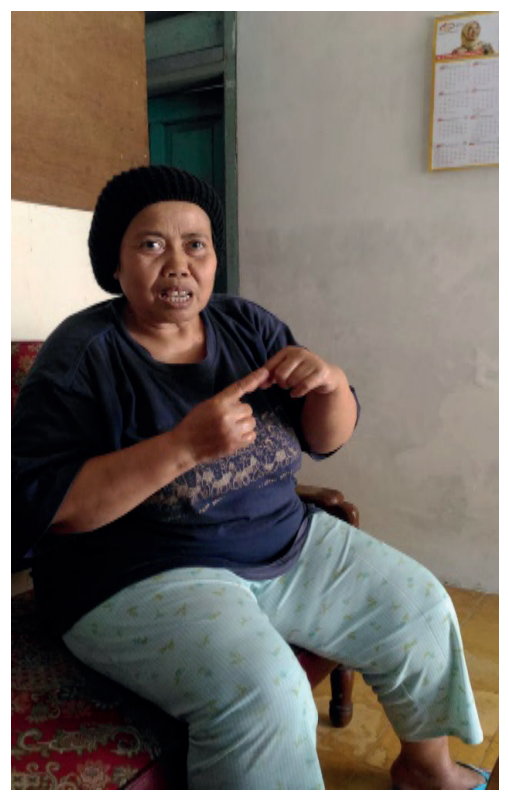

Figure 2. Profile of Therapist Mak Ida

One of the therapists said that he had fasted for 40 days, not having sahur (early breakfast), and when breaking his fasting, he only drinks a glass of water and eats only talas (taro). Besides that, when the night comes, he must not sleep and fill the night with reading wirid (personal prayers) instead. He slept only at noon (Ida, interview, Juli, 10th, 2018). It is different from the therapist in Ujang Saepulloh clinic where he learned to understand knowledge of traditional treatment and traditional medicine through books and his grandmother teaching who had learned from Haji Tarna, therapist Asep Saifuddin's father.

In searching the information of traditional medicine from the external side, fracture therapist gets the information from outside Citapen village. One of the therapists said that he have followed the activity of traditional treatment socialization and traditional medicine which held by the health institution in Bandung City ( $A$, Saifudin, interview, July 11th, 2018). This health institution sees the traditional treatment done by each therapist. From the explanation above, it can be seen that fracture treatment that uses traditional medicine has already met the standard of traditional treatment from the Minister of Health of the Republic of Indonesia.

Fracture therapists in evaluating the information on traditional medicine use information sources nearby. They do reconsideration toward the existing parents or relatives. For example, they ask the elders to find the medicinal herbs in their house surroundings and how to mix them. Now since medicinal herbs are getting rare to be found in their backyard, they begin to search them outside Citapen village. Moreover, next fracture therapist generation begins to use information sourced from printed media and online to find the disease symptoms had by the patients or try to find another medicinal herb as the anticipation or substitute.

When evaluating the information of traditional medicine that had been done, the fracture therapist uses that information. For example, Mak Ida said there was a patient who worked as a mechanic at the concrete stone factory. His leg was crushed by the container. From the hospital information, his leg must be amputated. Finally, the patient went to Mak Ida clinic. The therapist directly treated him by using traditional medicine of sago and tubers mixture and rubbed them to his legs by using cotton tied up with wood. The patient indeed recovered after two months of treatment. The patient with leg crushed got no massage treatment; they wrapped by traditional medicines. This was done because the leg bone was very thin (Ida, interview, July, 10th, 2018)

A therapist Mak Ida and Ujang Saepuloh made their organic materials mixture as the medicine for a pain reliever and a swollen reliever for the fracture patients. The organic materials are taken from the mixed tubers then apply it onto the fracture body's part. 
This is purely traditional, without chemical mixture. That also happened in Haji Obay Clinic and was continued by his son named Acep. During the treatment in the clinic, the patient is always given the traditional medicine made by the therapist, and then being compressed first by using sago and tubers such as turmeric which were pounded to take its juice and let them cold before they used. (Acep, interview, July 11th, 2018). In this clinic, they mix tubers as the materials for pain and fever reliever.

\section{Conclusions}

The conclusion has three points. First, in the information of traditional treatment needed, the fracture therapist help relieving the pain from the dislocated bone, relieve the swollen caused by broken bone, and help the process of connecting the broken bone. From the economic aspect, the community who are categorized to the middle and lower economic condition will be hard to be able to pay a the hospital treatment cost. Then, this community is helped by the traditional treatment, especially fracture clinic in Citapen village. Culturally local knowledge of traditional medicine in Citapen village has already done since the first fracture clinic appeared in Citapen village. People who suffer from bone fracture need treatment to recover their bone and therapists would make them feels easy and comfortable since they do not use medical pieces of equipment. Second, fracture therapists search information of traditional medicine from both internal and external sides. Third, in evaluating the information of traditional medicine, fracture therapists use nearby information sources. When evaluating the information on traditional medicine has been done, fracture therapists will use that information. Based on the result of the research, the fracture therapist still has a different paradigm with the department of health in their region. However, their local knowledge in the treatment are very important to help people from lower-class economy. Besides that, the traditional treatment is not mixed with chemical material which can harm the health. Therefore, the local health institution can work together with the fracture therapists and mixing the herbs or traditional treatment with modern treatments.

\section{References}

Anwar, R. K., Rizal, E., \& Saepudin, E. (2015)
'Kemampuan literasi informasi siswa tentang apotek hidup berbasis individual competence framework (Studi terhadap Siswa SMA di Kota Bandung)', Jurnal Kajian Informasi \& Perpustakaan, 3(1), pp. 9-32.

Anwar, S. J. (2012) 'Pengetahuan lokal (indigenous knowledge) "Pasompe" Bugis-Makassar dalam menjelajah nusantara', SOSIOLOGI REFLEKTIF, 7(1), pp. 65-76. Available at: http:// download.portalgaruda.org/article. php?article $=113339 \&$ val $=5181$.

Bawden, D. (2006) 'Users, user studies and human information behaviour', Journal of Documentation, 62(6), pp. 671-679.

Baxter, P. and Jack, S. (2008) 'The qualitative report qualitative case study methodology: Study design and implementation for novice researchers', The Qualitative Report, 13(4), pp. 544-559. doi: citeulikearticle-id:6670384.

Dubbeldam, I., Sanders, J., Spooren, W., Meijman, F. J., \& van den Haak, M. (2018) 'Motives for health information behavior: Patterns more refined than traditional dichotomies. A Study among women in a Cervix Treatment Process', Journal of Consumer Health on the Internet, 22(2), pp. 126-141. doi: 10.1080/15398285.2018.1425071.

Fakhri, M. et al. (2018) 'Occupational Health and Safety and Practical Code of Safety at An Indonesian Agrochemical Company', MIMBAR, Jurnal Sosial dan Pembangunan, 34(2), pp. 341-350.

Ismedsyah, Sembiring, S. A. (2019) 'Evaluasi implementasi regulasi pelayanan kesehatan tradisional empiris oleh penyehat tradisional di Kabupaten Karo', in Seminar Nasional Teknologi Komputer \& Sains (SAINTEKS): "Inovasi dan Pemanfaatan Teknologi Pembelajaran Daring di Era Revolusi Industri 4.0". Medan: STMIK Budi Darma, pp. 182-186.

Kundu, D. K. (2017) 'Models of information seeking behaviour: A comparative study', International Journal of Library and Information Studies, 7(4), pp. 393-405.

Kurnia, S. H., Kosasih, C. E., Prawesti P., A. (2012) 'Faktor-faktor yang melatarbelakangi pasien patah tulang berobat ke pengobatan tradisional ahli tulang di Sumedang', Students e-journal, $1(1)$, pp. 1-14.

Lioutas, E. D. (2014) 'Food consumer information behavior: Need Arousal, seeking behavior, and information use', Journal of Agricultural \& Food Information, 
RULLY KHAIRUL ANWAR, et al. Information Behavior of Fracture Therapist in Citapen Village, West Bandung...

$15(2)$, pp. 81-108.

Mason, J. (2002) Qualitative researching. London: Sage Publication Inc.

Menteri Kesehatan Republik Indonesia (2003) Menteri Kesehatan Republik Indonesia keputusan Menteri Kesehatan Republik Indonesia Nomor 1076/MENKES/SK/ VII/2003 tentang penyelenggaraan pengobatan tradisional. Indonesia.

Menteri Kesehatan Republik Indonesia (2007) Keputusan Menteri Kesehatan Republik Indonesia Nomor 381/MENKES/SK/ III/2007. Indonesia.

Pang, P. C.-I. et al. (2015) 'Conceptualising health information seeking behaviours and exploratory search: result of a qualitative study', Health and Technology. Springer, 5(1), pp. 45-55.

Patton, M. Q., Cochran, M. (2002) A Guide to Using Qualitative Research Methodology, Medecins Sans Frontieres. doi: 10.1109/ PROC.1978.11033.

Saepudin, E., Rusmana, A., \& Budiono, A. (2016) 'Penciptaan pengetahuan tentang tanaman obat herbal dan tanaman obat keluarga', Jurnal Kajian Informasi \& Perpustakaan, 4(1), pp. 95-106.

Starman, A. B. (2013) 'The case study as a type of qualitative research', Journal of Contemporary Educational Studies, 1(1), pp. 28-43.

Sudayasa, I. P. et al. (2019) 'Identifikasi Kajian Filosofis Penyehat Tradisional Pijat Patah Tulang Di Provinsi Sulawesi Tenggara' in Seminar Nasional Teknologi Terapan Berbasis Kearifan Lokal.

Suryana, F., Iskandar, J. (2014) 'Studi pengetahuan lokal tanaman obat pada agroekosistem pekarangan dan dinamika perubahannya di Desa Cibunar Kecamatan Rancakalong Kabupaten Sumedang-Jawa Barat', Bionatura-Jurnal IImu-IImu Hayati dan Fisik, 15(3), pp. 203-209.

Williamson, E. M. (2005) 'Interactions between herbal and conventional medicines', Expert Opinion on Drug Safety, 4(2), pp. 355-378.

Zhang, Y. (2013) 'The effects of preference for information on consumers' online health information search behavior', Journal of medical Internet research. JMIR Publications Inc., Toronto, Canada, 15(11), p. e234.

Zulkifli (2004) Pengobatan tradisional sebagai pengobatan alternatif harus dilestarikan, http://library.usu.ac.id. 